DOI https://doi.org/10.30525/978-9934-26-111-4-36

\title{
ДОСЛІДЖЕННЯ ГОЛОЦЕНОВИХ ГРУНТІВ \\ БАГАТОШАРОВОГО ПОСЕЛЕННЯ МАЛА \\ ГЛУМЧА-1 ТЕРИТОРІЇ ЖИТОМИРСЬКОГО ПОЛІССЯ
}

\author{
Матвіїшина Ж. М. \\ доктор географічних наук, професор, \\ завідувач сектору палеогеографії \\ Інститут географії Начіональної академії наук Украӥни \\ м. Київ, Україна \\ Пархоменко О. Г. \\ кандидат географічних наук, дочент, \\ завідувач кафедри географії \\ Національний університет «Чернігівський колегіум» \\ імені Т. Г. Шевченка \\ м. Чернігів, Україна
}

В наш час все більшу увагу привертають до себе пам'ятки культури. Всебічне вивчення археологічних комплексів, дає нам можливість більш точно відтворити умови формування та еволюції давнього суспільства. В останні десятиріччя проводяться дослідження археологічних об’єктів методами археології та палеогеографії, з метою реконструкції характеру змін ландшафтів району дослідження. Важливу роль в інтерпретації даних з археологічних об'єктів з використанням педологічних методів відіграли дослідження I.В. Іванова, В.А. Дьомкіна, О.Л. Александровського, Ю.Г. Чендєва, а в Україні Ж.М. Матвіїшиної, Н.П. Герасименко, Ю.М. Дмитрука, О.Г. Пархоменка, С.П. Дорошкевича, С.П. Кармазиненка, А.С. Кушніра та ін.

Завдяки активному розвитку досліджень голоценових грунтів 3 використанням нового напрямку досліджень - геоархеологічного стає можливим виявлення не лише різної інтенсивності, але й різної спрямованості грунтових процесів на окремих відрізках історії голоцену на археологічних об'єктах [1-5]. Одним з таких $є$ давньоруське поселення (X-XI ст. н.е.) неподалік с. Мала Глумча (Ємільчинського району Житомирської області), розташоване за 250-300 м на північний схід від с. Мала Глумча, за 2,0 км на захід від с. Паранине, за 150 м на північний схід від перехрестя польових доріг на підвищені посеред заплавної долини р. Бровник (рис.1). 


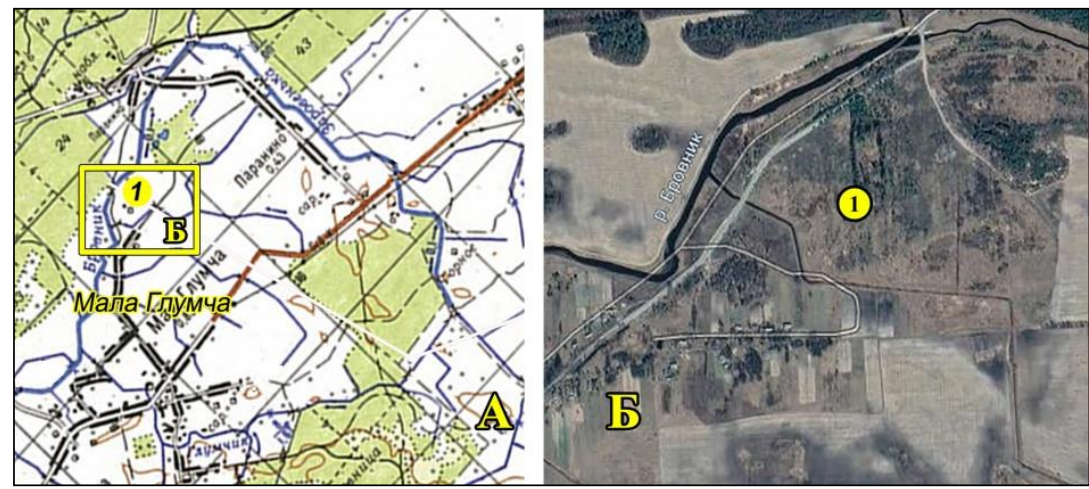

Рис. 1. Розташування пам'ятки:

А - місцерозташування розчисток (в межах поселення та фонового) об'єкту дослідження Мала Глумча-1 (Смільчинський район Житомирська область, Масштаб: 1 : 100 000); Б - ключова ділянка території дослідження

За запрошенням директора рятівної археологічної служби науководослідного центру Інституту археології НАНУ О. Осаульчука нами проведено палеопедологічні дослідження грунтів давнього поселення у трьох розчистках (розчистка №1 та №3 в межах давнього поселення та розчистка №2 сучасного (фонового) грунту, що дало можливість відтворити палеогеографічні обстановки часу існування поселень i порівняти їх із сучасними. (рис. 2,4,6).

Під час дослідження проведено детальний морфологічний опис $\mathrm{i}$ проаналізовано під мікроскопом шліфи 388 зразків. Мікроморфологічний аналіз передбачає вивчення зразків під мікроскопом в непорушеному стані і дає вагомі результати при уточненні генезису грунтів, оскільки фіксує деталі мікробудови, що не виявляються іншими методами. Особливо ефективне його використання для відтворення первинних грунтоутворювальних процесів (рис. 3,5,7).

Виявлено та досліджено рештки шістнадцяти стаціонарних об'єктів, з яких один належать до мезоліту, по одному - до ранньої доби бронзи та XII-XIII ст. Решта частина об'єктів важко віднести до конкретного культурно-хронологічного горизонту у зв'язку із відсутністю датуючого матеріалу. На пам'ятці отримано кількісно значний речовий матеріал. Вироби з кременю, кераміки у загальному співвідношенні становлять різночасовий археологічний комплекс [6]. 
РОЗЧИСТКА №1 розташована в межах давнього поселення на піщаній дюні, має такий профіль і представлена такими генетичними горизонтами.
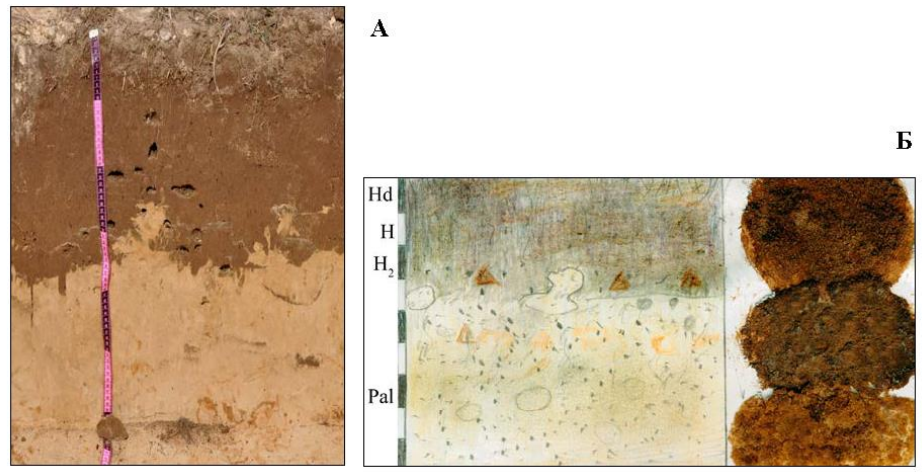
Рис. 2. Генетичні горизонти грунту у розчистці № 1: А - фото розчистки (ліворуч); Б - кольорова польова замальовка 3 примазками натурального матеріалу (праворуч).

\begin{tabular}{|c|c|}
\hline $\begin{array}{c}\text { Hd - } \\
\mathbf{0 , 0 - 0 , 0 4} \text { M }\end{array}$ & $\begin{array}{l}\text { бурувато-сірий з корінцями трав, піщаний, } \\
\text { перехід за зменшенням кількості коренів. }\end{array}$ \\
\hline$\underset{\mathbf{0 , 0 4 - 0 , 2 5} \text { м }}{\mathrm{H}-}$ & 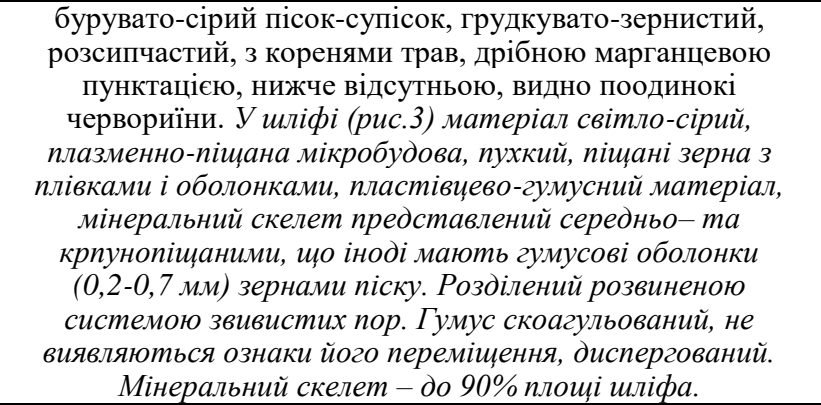 \\
\hline$\frac{\mathrm{H}_{2}-}{\mathbf{0 , 2 5 - 0 , 3 5} \text { м }}$ & $\begin{array}{c}\text { бурувато-сірий, розсипчастий пісок-супісок, з марганцевою } \\
\text { пунктацією, з поодинокими кротовинами до 6-7 см в } \\
\text { діаметрі, заповненими жовтуватим піском, перехід різкий за } \\
\text { кольором і зміною гранулометричного складу. У шліфі низу } \\
\text { гумусового горизонту спостерігаються піщані зерна } \\
(0,2-0,5 \text { мм), окатані, зі згустками плазми між зернами. } \\
\text { Суцільна маса пухка, зерна скелету розділені системою } \\
\text { звивистих пор. }\end{array}$ \\
\hline
\end{tabular}




\begin{tabular}{|c|c|}
\hline & жовтувато-світлосірий, розсипчастий пісок дюни, з \\
Pal - & окремими червориїнами, заповненими світлим гумусовим \\
матеріалом. На глибині 0,5 м слабко у вигляді смуги \\
$\mathbf{0 , 3 5 - 0 , 6} \mathbf{м}$ & проявляється шар озалізнення (недорозвинений ортзанд) у \\
& вигляді декількох плям. Під мікроскопом у шліфі помітні \\
& піщані зерна, деякі з них мають прозорі глинисті оболонки, \\
& однак є зерна і без оболонок, плазма майже відсутня. \\
& Поровий простір займає половину плоші шліфа. \\
\hline
\end{tabular}
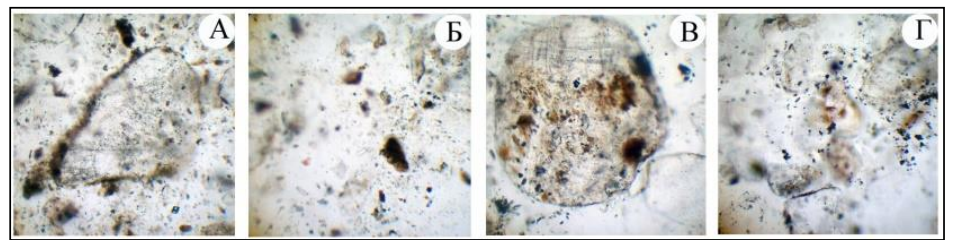

Рис. 3. Мала Глумча, розчистка № 1.

Мікробудова дернового трунту давньоруського поселення:

А - зерна піску з гумусовими оболонками в гумусовому горизонті;

Б - пухка мікробудова в низах гумусового горизонту;

В,Г - мікробудова розсипчастого піску породи. 3б.100, нік.

Грунт дерновий, піщаний, шари 3 артефактами X-XI ст. н.е. i відносяться до низів гумусового горизонту.

РОЗЧИСТКА №2 (фоновий грунт) закладено в 50 м від розчистки №1 за межами давньоруського поселення. Досліджено такий профіль 3 генетичними горизонтами.

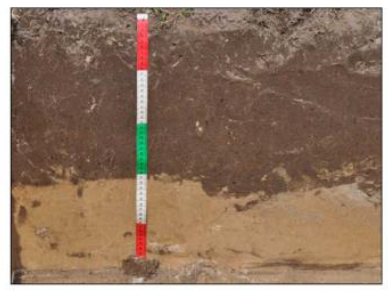

A

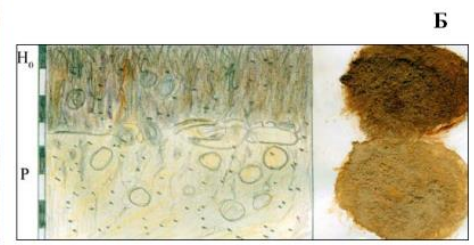

Рис. 4. Генетичні горизонти грунту в розчистці № 2:

А - фото розчистки (ліворуч);

Б - кольорова польова замальовка

з примазками натурального матеріалу (праворуч). 


\begin{tabular}{|c|c|}
\hline $\begin{array}{c}\text { Ho }-\mathbf{0 , 0 5 - 0 , 3 5} \\
\text { M }\end{array}$ & $\begin{array}{c}\text { бурувато-жовтосірий пісок, розсипчастий, по всьому } \\
\text { горизонту з марганцевими пунктаціями, червориїни } \\
\text { заповнені світло-жовтим матеріалом, межа чітка, } \\
\text { горизонтальна, проявляється при переході до світлішого } \\
\text { піску. У шліфі (рис.5) матеріал світло-сірий, помітні } \\
\text { рештки коренів трав, піщані зерна, маса слабо } \\
\text { профарбована гумусом, зерна складають } \\
\text { до 80-90\% площчі иліфа. }\end{array}$ \\
\hline$P-0,35-0,6$ м & $\begin{array}{l}\text { жовтувато-світлосірий, розсипчастий, з поодинокими } \\
\text { червориїнами, заповненими гумусовим матеріалом. } \\
\text { Під мікроскопом матеріал майже повністю складений } \\
\text { піщзаними зернами, без плівок і оболонок, система пор } \\
\text { займає } 80 \text { \% площчі шліфа. Це - алювіальний матеріал. }\end{array}$ \\
\hline
\end{tabular}

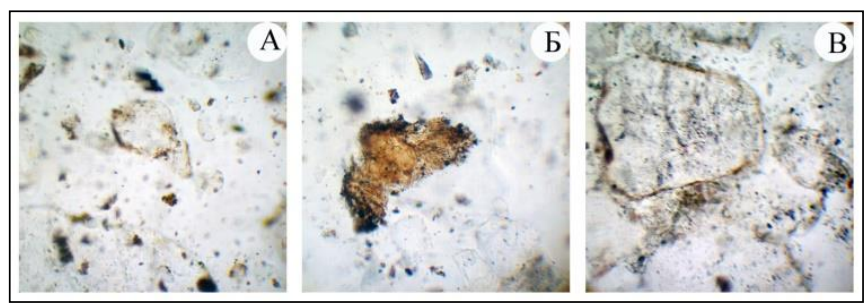

Рис. 5. Мала Глумча, розчистка №2. Мікробудова дернового фонового трунту: А,Б - супіщана пухка мікробудова, озалізнене зерно піску; В - піщані зерна породи. 3б.100, нік.//.

РОЗЧИСТКА № 3 розташована в пониженні дюни під осоковою рослинністю, має такий профіль і представлена генетичними горизонтами.
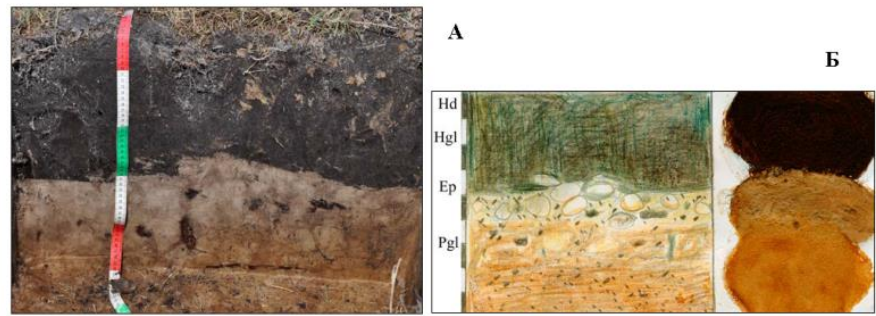

Рис. 6. Генетичні горизонти грунту в розчистці № 3:

А - фото розчистки (ліворуч);

Б - кольорова польова замальовка

3 примазками натурального матеріалу (праворуч). 


\begin{tabular}{|c|c|}
\hline $\begin{array}{l}\text { Hd - 0,0-0,1 } \\
\text { M } \\
\end{array}$ & $\begin{array}{l}\text { темно-сірий до чорного, } 3 \text { корінцями рослин, розсипчастий } \\
\text { пісок. }\end{array}$ \\
\hline $\begin{array}{c}\text { Hgl - } \mathbf{0 , 1 - 0 , 3 5} \\
\text { M }\end{array}$ & $\begin{array}{l}\text { темно-сірий до чорного, піщаний, розсипчастий, з великою } \\
\text { кількістю корінців трав. Нижня межа чітко горизонтальна } \\
\text { або слабо хвиляста за контрастом кольорів. У шліфі (рис.7) } \\
\text { матеріал світло-сірий, піщані зерна оконтурені гумосовою } \\
\text { плазмою і оболонками, зерна мінерального скелету пухко } \\
\text { упаковані, майже відсутня плазма, гумус типу муль і модер } \\
\text { у вигляді напівзгнилих коренів, багато фітолітів рослин. }\end{array}$ \\
\hline Ep - 0,3-0,4 м & $\begin{array}{c}\text { білясто-жовтувато-світлосірий, розсипчастий пісок-супісок, } \\
\text { переритий кротовинами до 6-12 см в d. Під мікроскопом } \\
\text { матеріал без плівок і оболонок, середньо піщцаного } \\
\text { гранулометричного складу, поровий простір займає більще } \\
\text { половини площчі шліфа. }\end{array}$ \\
\hline $\begin{array}{c}\text { Pgl }-0,4-0,6 \\
M\end{array}$ & $\begin{array}{c}\text { озалізнений пісок, жовтувато-бурий, з ініціальними } \\
\text { формами ортзандів і ознаками перезволоження, рештками } \\
\text { напівзгнилих кореневищ. У шліфі суиільний пісок, піщані } \\
\text { зерна пухко упаковані, поровий простір займає біля } 70 \% \\
\text { площчі шліфа. }\end{array}$ \\
\hline
\end{tabular}

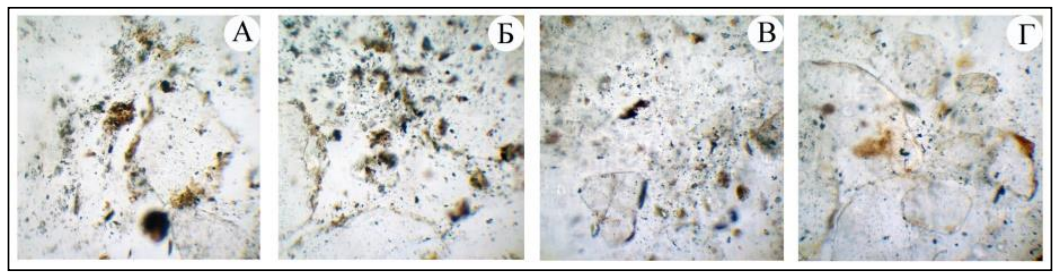

Рис.7. Мала Глумча, розчистка №3. Мікробудова болотного трунту в основі дюни: А,Б - мікробудова гумусово-мулуватого горизонту з рештками корінців; В - світлий пісок; $\Gamma$ - розсипчастий пісок. 3б.100, нік.//.

Зверху простежено чорний мулувато-болотний, опідзолений шар болотного грунту. Грунти дюни на поселенні і фоновий мало відрізняються між собою i мають майже однакову потужність гумусових горизонтів (біля 0,35 м). У матеріалі грунту поселення матеріал в інтервалі 0,25-0,35 м дещо пухкіший, але в обох розчистках грунти можна визначити як дернові, що сформувалися на пісках дюни. Грунт пониження несе риси алювіально-болотного, однак і він значно переритий кротовинами. Як $\mathrm{i}$ в наш час, так $\mathrm{i}$ в давні часи 
функціонування поселення формувалися дернові зональні грунти півдня лісової зони з помірним кліматом.

\section{Література:}

1. Матвіїшина Ж.М., Пархоменко О.Г. Голоценові грунти давніх поселень на Полтавщині (на прикладі Бєльського городища). Матеріали Всеукраїнської науково-практичної конференції, присвяченої 160-річчю 3 дня народження В.В. Докучаєва. Суми: СумДПУ ім. А.С. Макаренка. 2006. С. 103-109.

2. Матвіїшина Ж., Пархоменко О., Ногін Є. Палеопедологічні дослідження давніх поселень на Сумщині. Львів: ЛНУ імені І.Франка. 2013. C.253-256.

3. Матвіїшина Ж.М., Пархоменко О.Г., Скороход В.М. Еволюція грунтів та ландшафтів території давньоруського городища біля с.Виповзів на Чернігівщині. Наукові записки Вінницького державного педагогічного університету імені Михайла Коцюбинського. Серія: Географія. 2019. Вип.31, №1-2. С.20-31.

4. Матвіїшина Ж.М., Пархоменко О.Г. Зміни грунтів і ландшафтів за даними комплексних досліджень багатошарового кургану неподалік с. Бурти на Черкащині. Наукові записки СумДПУ імені А.С. Макаренка. Географічні науки. Вип. 10. 2019. С.25-46.

5. Матвї̈шина Ж.М., Пархоменко О.Г. Палеопедологічні дослідження грунтів двошарового поселення неподалік с. Кривохиженці на Вінниччині. Наукові записки СумДПУ імені А.С. Макаренка. Географічні науки. Випуск 1 2020. Том 2. м. Суми. С.72-87.

6. Милян Т., Назар I., Петраускас А., Петраускас О., Сало Б., Чорний А. Звіт про результати пам'ятко-охоронних робіт (розкопок) на території Рівненської та Житомирської областей у зоні будівництва, експлуатація та обслуговування ПЛ 750 кВ Рівненська АЕС ПС 750 кВ «Киӥвська» та заходу ПЛ 750 кВ Хмельницька АЕС Чорнобильська АEC на ПС 750 кВ «Київська» у 2011-2012 pp. // Науковий архів ІА НАН України.- Т. 1. 